\title{
Tissue localization of betacyanins in cactus stems
}

\section{Localización de betacianinas en tejido del tallo de cactus}

\author{
Alessandro Mosco \\ Department of Life Sciences, University of Trieste, Via Licio Giorgieri 5 I-34127 Trieste, Italy. \\ \alessandro.mosco@phd.units.it
}

\begin{abstract}
Betalains are soluble pigments found only in the suborder Chenopodiniae, while in all other Angiospermae they are replaced by anthocyanins. The convergent evolution of the presence of anthocyanins and betalains in vegetative tissues supports the hypothesis of a similar function, based on the absorption properties of these pigments. The screening effect of anthocyanins results in the reduction of the amount of photoinhibition. Betalains, being the anthocyanin counterpart in most families of Caryophyllales, were also suggested to have a screening role. This study is aimed at identifying in which Cactaceae stem tissues betacyanins, reddish to violet betalain pigments, accumulate. Stem accumulation of betacyanins was observed in cacti both in their natural habitat and in cultivation. The localization of betacyanins was assessed by light microscope studies on tubercle transverse sections. During 2 field trips in distinct years to the Mexican plateau in March, many cactus species, belonging to different genera, were observed displaying a reddish stem. Light microscope studies on cultivated plants showed that betacyanins accumulate in the hypodermis and in the outer layers of the chlorenchyma, where they may act as a screen, thus protecting the photosystems present in the underlying chlorenchyma, and have a possible antioxidant function in the cortex.
\end{abstract}

Key words: betacyanins, cacti, epidermis, hypodermis.

Resumen. Las betalaínas son pigmentos solubles que se encuentran sólo en el suborden Chenopodiniae, mientras que en el resto de Angiospermae, lo que existe son antocianinas. La evolución convergente de la presencia de antocianinas y betalaínas en tejidos vegetativos apoya la hipótesis de una función similar, que se basa en las propiedades de absorción de estos pigmentos. El efecto pantalla de las antocianinas resulta en la reducción de fotoinhibición. Siendo las betalaínas la contraparte antocianítica en la mayoría de las familias de Caryophyllales, se sugirió también un papel de pantalla de estos pigmentos. Este estudio tiene por objeto identificar los tejidos del tallo de los cactus en los cuales se acumulan las betacianinas. Esta acumulación se observó en tejidos tanto cultivados, como en la naturaleza. La localización de las betacianinas en los tallos de los cactus se observó en estudios de microscopía de luz en secciones transversales de tubérculos. Durante el trabajo de campo en la planicie mexicana en marzo, se observaron tallos rojizos en muchas especies de cactus de diferentes géneros. Los estudios en microscopía de luz mostraron que las betacianinas se acumulan en la hipodermis y en las capas más externas del clorénquima, donde pueden funcionar como pantalla, protegiendo los fotosistemas presentes en la capa subyacente, y posiblemente como antioxidante en la corteza.

Palabras clave: betacianinas, cactus, epidermis, hipodermis.

\section{Introduction}

Cacti are widespread in the arid lands of the New World, characterized by a desert climate with low rainfall, high temperatures and high irradiance. Adaptations, such as a succulent stem, crassulacean acid metabolism (CAM), spines, pubescence, and epidermal features, allow these plants to successfully cope with the environmental stresses.

Also, epidermal characteristics can influence the way plants react to xeric conditions. A thick cuticle, due to large deposits of cutin, can serve as a protective layer

Recibido: 29 abril 2011; 03 octubre 2011 against erosion and limits water loss (Loza-Cornejo and Terrazas, 2003). Epicuticular wax as well as epidermal trichomes can exert a protective role by reflecting incident light. For instance, the wax covered leaves of Cotyledon urbiculata can reflect as much as $60 \%$ of the incident light, thus acting as a photoprotection mechanism (Robinson and Osmond, 1994). Foliar trichomes of some Tillandsia species proved to be able to reflect $18-40 \%$ of the incident light suggesting that these structures have a protective role against photoinhibition (Pierce, 2007). A similar role can be ascribed to the wax covering of some cacti that renders their stems grey, bluish, silvery or white (Gibson and Nobel, 1986), and to the white trichomes present on the stem of Astrophytum species (Anderson, 2001). Cactus epidermis is 
usually composed of a single layer of square to rectangular cells, while in some species subsequent cell divisions lead to the building of a multiseriate epidermis (Mauseth, 2006). The walls of epidermal cells are mostly thin except in a few taxa of Armatocereus, Cereus, Jasminocereus, and Mammillaria, where the external wall is thicker than the internal walls (Loza-Cornejo and Terrazas, 2003). Epidermis surface can be smooth due to flat periclinal cell walls, or the periclinal cell walls can be convex, giving a rough texture to the surface (Terrazas-Salgado and Mauseth, 2002). Hypodermis is absent in Pereskioideae, while in Opuntioideae and Cactoideae it consists of 1 to several cell layers (Terrazas-Salgado and Mauseth, 2002). The cell layers can be collenchymatous with thick cell walls providing a mechanical support and a barrier against pathogens. A singlelayered hypodermis with thin-walled cells was reported for some species of Ariocarpus, Echinocereus, Mammillaria, Peniocereus, and Sclerocactus (Loza-Cornejo and Terrazas, 2003). Biominerals identified in cactus tissues are mainly calcium oxalates and silicon dioxides, while only recently calcium carbonate and magnesium oxalate deposits were found in the Opuntioideae (Monje and Baran, 2002; Monje and Baran, 2004; Monje and Baran, 2005). Silica bodies and calcium oxalate crystals are found both in the epidermis or hypodermis and are thought to protect the plant from foraging insects, while calcium oxalate crystals may also be involved in calcium regulation (Gibson and Nobel, 1986; Nakata, 2003).

Epidermis and hypodermis can act also as a screen toward UV-A and UV-B radiation, thus protecting chlorenchyma from shortwave radiation, as was shown for the epidermis and hypodermis of Carnegiea gigantea, where these tissue layers with a thickness of $1 \mathrm{~mm}$ can block all ultraviolet radiation, but still enable the transmission of nearly $68 \%$ of photosyntheticlly active radiation (PAR) (Darling, 1989). Also, in Opuntia engelmannii and Opuntia phaecantha the structure of the epidermis and hypodermis is sufficient to block up to $94 \%$ of the UV-B radiation, while nearly $50 \%$ of the incident UV-A is screened by soluble flavonoids present in the epidermis (Cockell et al., 2004).

Additionally, soluble pigments such as anthocyanins have been proposed to have a screening role, thus reducing light induced stress, which can lead to photoinhibition and photobleaching of chlorophyll (Steyn et al., 2002; Fondom et al., 2009). Anthocyanins can be found in nearly all Angiospermae, but in the suborder Chenopodiniae within the Caryophyllales (Clement and Mabry, 1996) and in some genera of higher fungi (Gill, 1994) another group of pigments is found, the betalains. Both chemical groups represent water-soluble vacuolar pigments. Anthocyanins are a class of flavonoids derived from phenylalanine, with a colour range from orange to blue. Instead, betalains are alkaloids derived from tyrosine, classified into yellow betaxanthins and red betacyanins (Tanaka et al., 2008). Both pigments are present mainly in the epidermal and hypodermal layers of reproductive and vegetative tissues. They are involved in pollination and seed dispersal, conferring attractive colours to flowers, fruits, and seeds, while their presence in vegetative tissues is regulated by environmental conditions (Stafford, 1994). As well as their involvement in reproduction, anthocyanins exert several other functional roles, like giving protection from UV-B, having a screen role for the photosynthetic apparatus, or acting as free radical scavengers (Gould, 2004). Though betalain biochemical properties are less known, being betalains the anthocyanin counterpart in most families of Caryophyllales, similar functions can be assumed. In Mesembryanthemum crystallinum betacyanin accumulation is induced by high light irradiance, so that a protective role can be assumed also for these pigments (Ibdah et al., 2002). Indeed, it has been shown that they may serve as osmoregulators, as well as having antiradical and antioxidant properties (Cay et al., 2003; Stintzing and Carle, 2004). Stress induced accumulation in Cactaceae has been reported insofar only for 1 species. It was observed that in Opuntia macrocentra betacyanins accumulate in the stems as a response to cold or drought induced stress (Powell and Weedin, 2004).

The present study is aimed at investigating if betacyanin deposits are present also in the stems of other cactus species and to identify in which stem tissue this pigment accumulates. In order to do this several Cactaceae were observed both in their natural habitat and in cultivation and the stem localization of betacyanins was identified by light microscopy.

\section{Materials and methods}

Over the course of 10 years, several species of Mexican Cactaceae were observed in cultivation, as well as in their natural habitat, during 4 successive trips to the Mexican plateau in March (dry season) and August/September (rainy season) (Table 1). Cultivated plants originated mostly from documented seeds and were grown in xeric conditions in a south facing position. They were kept outside from April to September and watered once a week. In September watering was diminished and withheld by October, the plants then were kept dry until April when watering was restarted. From October to March they were kept indoors on a veranda, experiencing low nocturnal temperatures of $5.7^{\circ} \mathrm{C}$ average in January, which is the coldest month, and that could rise on sunny days to more than $30^{\circ} \mathrm{C}$.

Five cultivated species, 1 specimen/species, belonging to different genera, Leuchtembergia principis, Mammillaria sartorii, Obregonia denegrii, Thelocactus 
buekii and Thelocactus conothelos ssp. flavus, were used for anatomical studies. Tubercles were cut at their base and transversally sectioned on a vibratome at $15 \mu \mathrm{m}$ thickness. Sections were quickly observed under a light microscope before the water soluble pigments could diffuse outside the cells. Evaluated features were the thickness and number of layers of epidermis and hypodermis, and the presence of betacyanins. These morphometric values, as well as the mean and standard deviation, were obtained from 12 measurements made on the same specimen using ImageJ (http://rsbweb.nih.gov/ij/). To assess if the pigments found in the cactus tissues were betacyanins, absorption spectra, as well as chemical reactions to acidic and alkaline conditions were used. Tissue samples were macerated in methanolic $\mathrm{HCl}(1 \% \mathrm{HCl}$ in methanol) or in water, centrifuged at 14 $000 \mathrm{~g}$ for $10 \mathrm{~min}$, the supernatant collected, and set aside for the successive analyses. The absorption spectra (480$580 \mathrm{~nm}$ ) of the extracts were recorded using a Jenway 6310 spectrophotometer. To test the reaction to acidic conditions, $100 \mu \mathrm{L}$ of extract were diluted with an equal volume of $\mathrm{HCl} 2 \mathrm{M}$ and boiled for 5 minutes. The reaction to alkaline conditions was performed using $100 \mu \mathrm{L}$ of extract to which $\mathrm{NaOH} 2 \mathrm{M}$ was added drop-wise.

\section{Results}

During the field trips to the Mexican plateau in March, many cactus species belonging to different genera, Ariocarpus, Coryphantha, Echinfossulocactus, Ferocactus, Leuchtembergia, Mammillaria, Opuntia, and Thelocactus, were observed displaying a reddish stem. The localities visited were in the states of Coahuila, Nuevo León, and San Luis Potosí, which are characterized by a dry climate

Table 1. List of Mexican cacti observed in the field, during 4 successive years, and those observed in cultivation for a period of 10 years, and used for anatomical studies

\begin{tabular}{lccc}
\hline observed species & $\begin{array}{c}d r y \\
\text { season }\end{array}$ & $\begin{array}{c}\text { rainy } \\
\text { season }\end{array}$ & studied \\
\hline Ariocarpus fissuratus & $\mathrm{X}$ & $\mathrm{X}$ & \\
$\begin{array}{l}\text { Echinofossulocactus multicostatus } \\
\text { Ferocactus hamathacanthus }\end{array}$ & $\mathrm{X}$ & & \\
Leuchtembergia principis & $\mathrm{X}$ & $\mathrm{X}$ & \\
Mammillaria sartorii & $\mathrm{X}$ & $\mathrm{X}$ & $\mathrm{X}$ \\
Mammillaria winterae & $\mathrm{X}$ & $\mathrm{X}$ & $\mathrm{X}$ \\
Obregonia denegrii & $\mathrm{X}$ & $\mathrm{X}$ & $\mathrm{X}$ \\
Opuntia imbricata & $\mathrm{X}$ & $\mathrm{X}$ & \\
Thelocactus buekii & $\mathrm{X}$ & $\mathrm{X}$ & $\mathrm{X}$ \\
Thelocactus conothelos & $\mathrm{X}$ & $\mathrm{X}$ & \\
Thelocactus conothelos ssp. flavus & $\mathrm{X}$ & $\mathrm{X}$ & $\mathrm{X}$ \\
Thelocactus hexaedrophorus & $\mathrm{X}$ & $\mathrm{X}$ & \\
Thelocactus tulensis & $\mathrm{X}$ & $\mathrm{X}$ & \\
\hline
\end{tabular}

of type B of the Köppen classification with summer rains, distributed mainly in July, August, and September, while February and March are the driest months (Vidal-Zepeda, 2005). Of the species evaluated during the field trips, only T. buekii was observed both in the dry and rainy seasons, each in different populations. T. buekii specimens observed during the winter period have characteristic dark red stems that turned green during the summer rainy period (Fig. 1). This seasonal variation was also observed in cultivated specimens that were grown in conditions that mimicked the environmental conditions found in the Mexican plateau, as these cacti were watered through May to September and kept dry during the remaining months. Pigments accumulate in the whole stem in low flat stemmed plants, or on the stem side which received the most irradiation, or in tubercle tips and or tubercle upper sides, which are the most exposed surfaces to the sun (Fig. 2).

Because anthocyanins and betacyanins have similar colour ranges, absorption spectra and chemical analyses were used to assess the presence of betacyanins. Recorded absorption spectra (Fig. 3) had a maximal absorption that was in the range of betacyanins (Table 2). The extracts subjected to the acidic reaction lost their colour, while in alkaline conditions their colour turned yellow. Chemical tests and maximal absorption proved that the pigments present in the tissues were betacyanins.

The anatomical observations revealed different distribution patterns of the pigments in particular tissue layers of the tubercle cross-sections of the 5 species studied (Table 2). The amount of tubercle pigmentation is variable even in a single specimen, and can affect in part or completely the tubercle surface. Betacyanin deposits were observed underneath the epidermis only in correspondence of the reddened tubercle surface.

In $M$. sartorii betacyanins accumulated on the upper side of the tubercles which was reflected at the anatomical level by a red layer present in correspondence of the upper side of the tubercle. The same was true for the studied Thelocactus specimens, where a pigmented layer was found in the upper side of the tubercles, while in $O$. denegrii and L. principis betacyanin deposits were present in the entire perimeter of the tubercles. In general, the pigmentation can affect partly or completely the tubercle surface, therefore betacyanin deposits are found along the entire perimeter of the tubercle or in part. In L. principis, which had a uniseriate epidermis and a collenchymatous hypodermis, betacyanins were found mostly in the outermost hypodermal layer. Innermost hypodermal layers were rich in druses with sparse cells containing red pigments. Small amounts of betacyanins were observed also in the cortical chlorenchyma, where they tinge the cells a pink colour (Table 2, Fig. 4A). The epidermis of M. sartorii 
Table 2. Number of layers, thickness (mean \pm standard deviation) of epidermis and hypodermis, betacyanin localization, and betacyanin absorption maxima of the studied cactus species

\begin{tabular}{|c|c|c|c|c|c|c|}
\hline & \multicolumn{2}{|c|}{ Epidermis } & \multicolumn{2}{|c|}{ Hypodermis } & \multicolumn{2}{|l|}{ Betacyanins } \\
\hline & $\begin{array}{c}\text { Number of } \\
\text { layers }\end{array}$ & $\begin{array}{l}\text { Thickness } \\
\quad(\mu m)\end{array}$ & $\begin{array}{c}\text { Number of } \\
\text { layers }\end{array}$ & $\begin{array}{c}\text { Thickness } \\
(\mu \mathrm{m})\end{array}$ & Localization & $\begin{array}{c}\text { Absorption } \\
\text { maximum } \\
\text { (nm) }\end{array}$ \\
\hline Leuchtembergia principis & 1 & $78 \pm 7$ & 3 & $128 \pm 25$ & Hypodermis and outer chlorenchyma & 541 \\
\hline Mammillaria sartorii & 1 & $31 \pm 5$ & $1-2$ & $57 \pm 12$ & $\begin{array}{l}\text { Hypodermis (rare) and outer } \\
\text { chlorenchyma }\end{array}$ & 535 \\
\hline Obregonia denegrii & 1 & $25 \pm 3$ & $2-3$ & $81 \pm 11$ & Hypodermis & 526 \\
\hline Thelocactus buekii & 1 & $107 \pm 17$ & 1 & $23 \pm 6$ & Hypodermis & 537 \\
\hline Thelocactus conothelos ssp. flavus & 1 & $104 \pm 15$ & 1 & $31 \pm 5$ & Hypodermis & 533 \\
\hline
\end{tabular}
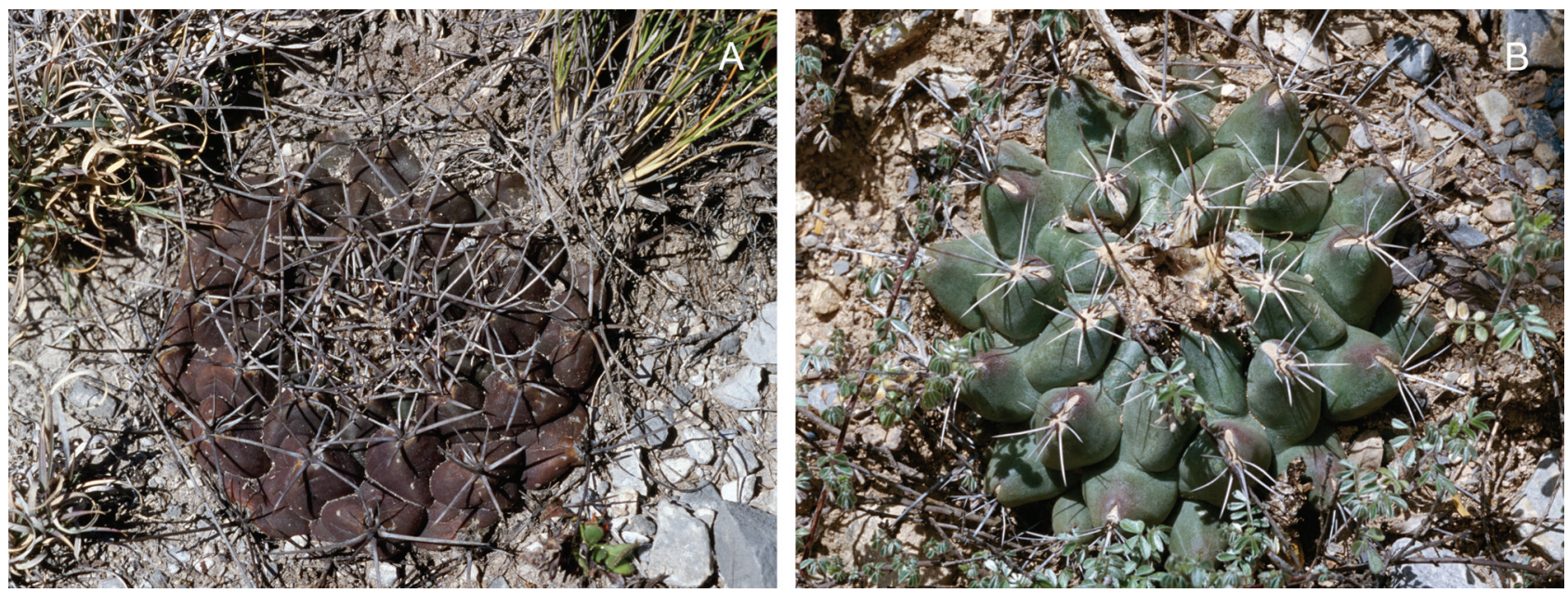

Figure 1. Thelocactus buekii in Nuevo León, Mexico. A), Thelocactus buekii photographed in March, during the dry season, showing a dark reddish stem due to accumulation of betacyanins. B), Thelocactus buekii photographed at the end of the rainy season, in September. The stem is green with only tubercle tips showing a reddish colour.
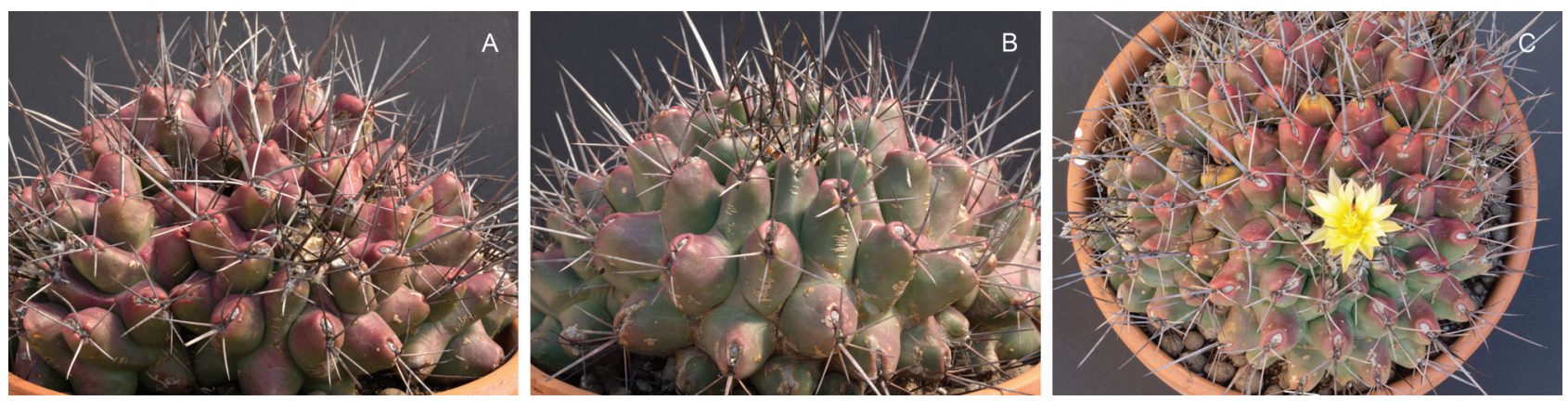

Figure 2. Thelocactus conothelos ssp. flavus in cultivation. A), the south facing side of the plant showing a deep red colouration of the stem as a result of betacyanin accumulation in response to high irradiation. B), the north facing side of the same plant that is greener in colour due to the less exposure to the sun. C), top view of the specimen. The difference in pigmentation between south and north facing sides is evident.

was uniseriate, while the hypodermis had 1 or 2 layers of thick-walled cells. Betacyanins were mainly present in the outermost layers of the cortical chlorenchyma, while only few cells of the hypodermis were pigmented (Table 2 ). Crystals or druses were not observed in this species (Fig. 4B). Obregonia denegrii showed a thin epidermis, and a multiseriate hypodermis (Table 2). The presence of betacyanins was restricted to the collenchymatous hypodermis, where many druses were observed too (Fig. 4C). Thelocactus buekii and T. conothelos ssp. flavus had a uniseriate epidermis with elongated cells, and a singlelayered hypodermis (Table 2). Betacyanins were present 


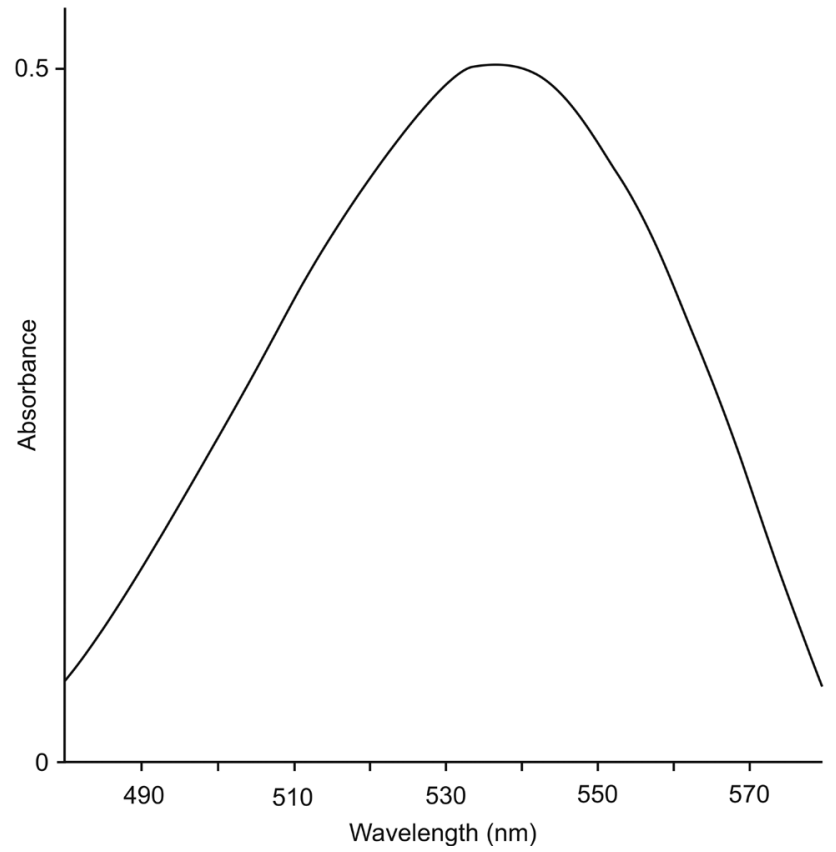

Figure 3. Absorption spectrum of the extract from the epidermis of Leuchtembergia principis. The maximum absorption was recorded at $541 \mathrm{~nm}$. only in the hypodermis, and no other cell inclusions were found (Fig. 4D).

\section{Discussion}

This study shows that several cactus species may respond to the stress induced by high irradiation with a reddening of the most exposed stem surfaces, due to the accumulation of betacyanins in the hypodermis and chlorenchyma. The adaptive strategy adopted by cacti to cope with the harsh environment they inhabit, characterized by strong irradiation, high temperatures, and low rainfall, involves both structural and physiological features, such as the reduction or absence of leaves, a succulent stem able to store large amounts of water, a thick epidermis with a reduced number of stomata and CAM system. All these features taken together contribute to a better management of available hydric resources.

To cope with strong irradiation, cacti have developed some protective structures such as spines, apical pubescence, stem trichomes and epicuticular waxes. Furthermore, the protective role of epidermis and hypodermis is well established. Being opaque to short
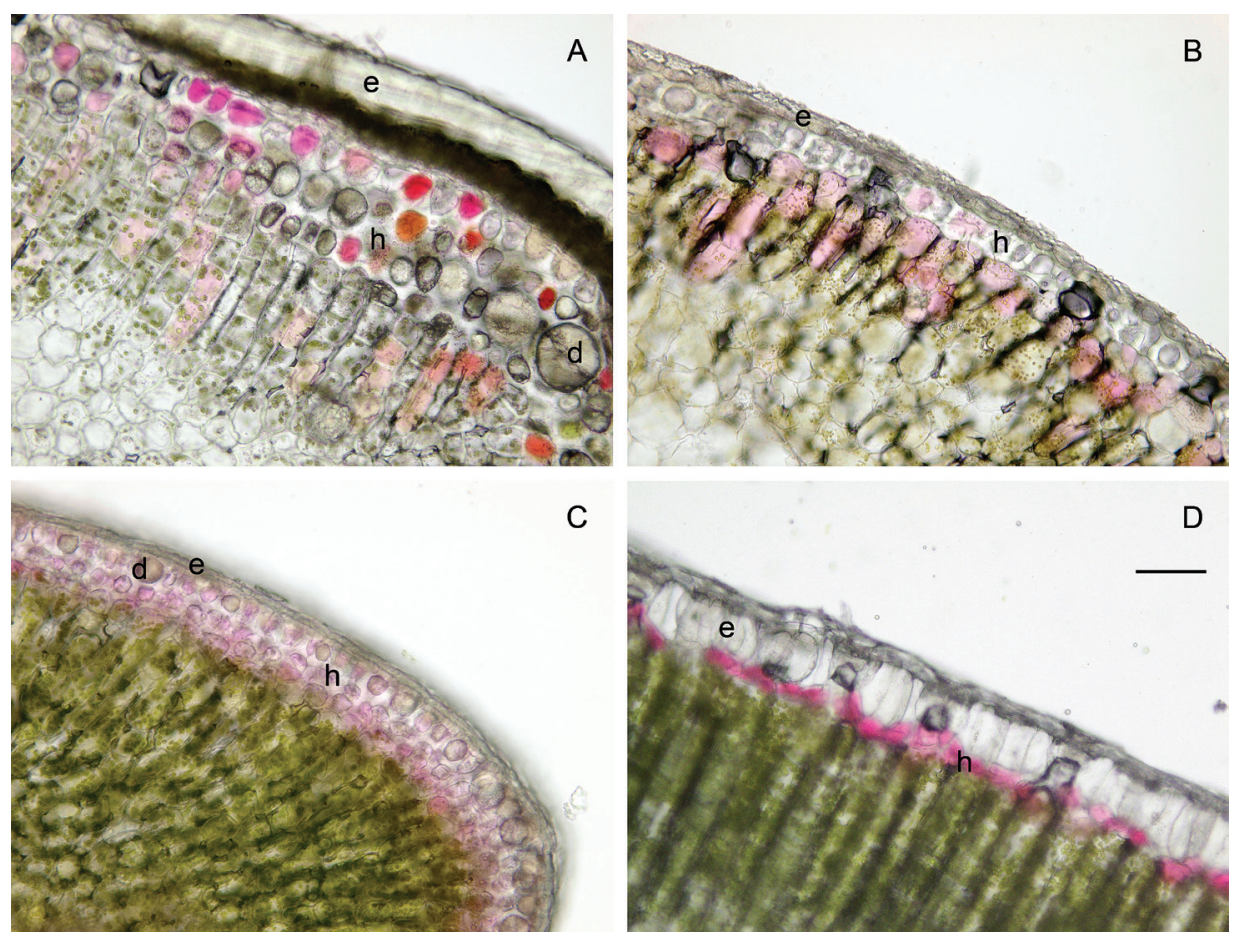

C

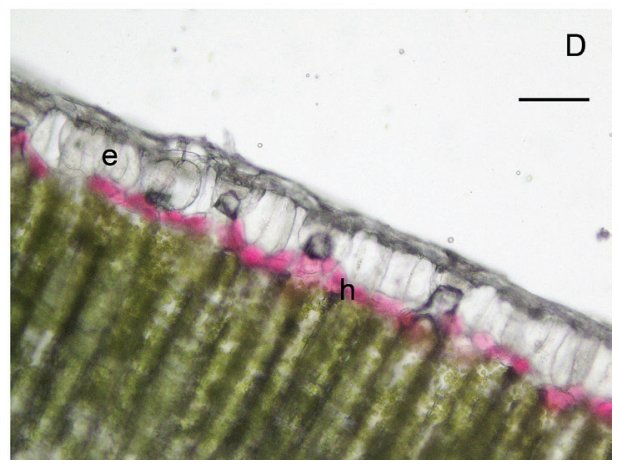

Figure 4. Tubercle transverse sections. A), Leuchtembergia principis - betacyanins accumulate mostly in the hypodermis cells and in lesser amounts in some chlorenchyma cells. B), Mammillaria sartorii - betacyanins are found mainly in the outer chlorencyma cells, while only few hypodermis cells accumulate it. C), Obregonia denegrii - betacyanins are present only in the hypodermis. D), Thelocactus buekii - a magenta coloured hypodermis due to the presence of betacyanins. Scale bar is $100 \mu \mathrm{m}, \mathrm{d}=$ druse, $\mathrm{e}=$ epidermis, $\mathrm{h}=$ hypodermis. 
wave radiation, but allowing the transmission of nearly $68 \%$ of PAR, means that the epidermal hypodermis can act efficaciously as a screen (Darling, 1989). At present the accumulation of betacyanins in the epidermal layers has not yet been considered as a protective mechanism in Cactaceae.

Vogt et al. (1999) showed that white light intensities of $500 \mu \mathrm{E}$ induced a rapid accumulation of complex, substituted flavonoids and betacyanin in Mesembryanthemum crystallinum, the pigments being synthesized in the epidermal bladder cells. Metabolite accumulation started $18 \mathrm{~h}$ after light irradiation, and the strongest increase in betacyanin concentration was detected from 72 to $120 \mathrm{~h}$, thereafter the accumulation ceased. Control plants exposed to light intensities of 100-200 $\mu \mathrm{E}$ showed no pigmentation. Apart from light intensity, the wavelength of light irradiating the samples was proved to be important in inducing betacyanin and flavonoid accumulation in $M$. crystallinum. The highest increase in both types of metabolites was observed at 335 $\mathrm{nm}$ and $320 \mathrm{~nm}$ cut-offs, the results showing that pigment accumulation is mainly due to UV-B radiation (Ibdah et al., 2002).

Stem reddening in the studied cacti is variable. In the 5 globose species studied in cultivation, L. principis, $M$. sartorii, O. denegrii, T. buekii, and T. conothelos ssp. flavus, betacyanin accumulates only in the equatorial facing side, and as these species possess tuberculate stems, betacyanin accumulates only on those surfaces that are unshaded by the protruding tubercles. In L. principis, which has long triangular tubercles, only tubercle tips were reddish. In the wild species of different genera were observed it was found that the degree and localization of stem pigmentation is variable and depends on the protection from the sun offered by nearby grasses, plants or rocks. In the open areas, cacti were almost completely pigmented, without displaying a side oriented accumulation, which may be explained by the higher solar elevation angle at latitudes in northern Mexico compared to that of Trieste, where the cultivated plants were studied. Preliminary observations on several populations of $T$. buekii in their natural habitat showed that in the winter months the plants had dark red stems that were not found during the summer months. The accumulation of red pigments in the winter suggests the correlation between high irradiance coupled with water stress due to the winter drought typical of the climate of this region and thus may prevent or reduce photoinhibition. This observation corroborates the hypothesis that high irradiance alone may not be the causal agent of photoinhibition in the field and that presence of other stresses, like drought or temperature extremes, may make the plants more sensitive to damage of their photochemical processes (Nobel, 1988; Murata et al.,
2007). Photoinhibition due to high irradiance coupled to extended drought has been proven in the wild for Opuntia basilaris. Diurnal measurements of low temperature (77K) fluorescence at $690 \mathrm{~nm}$ showed that the ratio $\mathrm{Fv} /$ Fm (variable fluorescence over maximum fluorescence) decreased during the day in relation with the increase of incident photon flux area density at a higher degree in the south facing cladode surfaces compared to the north facing pad sides that receive less total daily PAR (Adams, Smith and Osmond, 1987). Along with light intensity, the wavelength of irradiating light seems to be important in inducing betacyanin and flavonoid accumulation. In $M$. crystallinum it has been shown that the highest increase in both types of metabolites was observed at $335 \mathrm{~nm}$ and $320 \mathrm{~nm}$ cut-offs, the results showing that pigment accumulation is mainly due to UV-B radiation (Ibdah et al., 2002). Also, anthocyanins accumulate after UV exposure, but their filtering ability is questioned by the fact that these pigments are found mainly in the chlorenchyma cells instead of the epidermal or hypodermal layers, where they could better intercept incident UV radiation (Hatier and Gould, 2009). On the contrary betacyanins in cactus stems were found mainly in the hypodermis and outer layers of the chlorenchyma, therefore it can be supposed that they may serve as protection from UV-B radiation, having these pigments also an absorption peak in the UV range (270$280 \mathrm{~nm}$ ).

Light stress was shown to induce the synthesis of specific betacyanins in cactus stems that may serve as biomarkers (Wybraniec et al., 2010). In their study conducted to identify the pigments accumulated in cactus stems as a response to strong light, the stems of several cactus species were exposed to sunlight for 1 year until a violet-brown stem colour developed and the identities of the pigments were characterized. The prevailing betacyanins in Hylocereus polyrhizus, Epiphyllum phyllanthus, and Rhipsalis rhombea were 5"-O-E-feruloyl-2'-O-ß-apiosylbetanin and 5"-O-E-sinapoyl-2'-O-ß-apiosyl-betanin, while in Rhipsalis regnellii sinapoylated betacyanins were the main pigments. These betacyanins were identified as the most representative markers of light stress in the studied species. Additionally, betanin was found at low concentrations in most samples.

The presence of betacyanins in the hypodermis and outer chlorenchyma of the studied cacti is in agreement with the distribution data for betalains and anthocyanins, which are stored in the vacuoles of reproductive and vegetative tissues, mainly accumulating in the epidermis and sub-epidermal layers (Stafford, 1994). Betacyanin localization seems to be species specific, since in the 2 Thelocactus species studied and in $O$. denegrii the pigments are restricted to the hypodermis, while in L. principis and 
M. sartorii betacyanins were found in the hypodermis and outer chlorenchyma. This may prove to be of some value in taxonomy, moreover considering that in the same genus some species are prone to accumulate betacyanins, such as T. buekii, and others are not, such as Thelocactus bicolor. The convergent evolution of the presence of red pigments in vegetative tissues supports the hypothesis of a similar function, which is based on the similar absorption properties of these pigments (Steyn et al., 2002). The screening effect of anthocyanins results in the reduction of the amount of photoinhibition by absorbing excess photons otherwise captured by chlorophyll $b$ as well as in a lowered production of superoxide radicals by chloroplasts (Gould et al., 2002; Neill and Gould, 2003). As shown in the halophyte Sueda japonica grown under photoinhibitory conditions of low temperature and high intensity light, which promote accumulation of betacyanins in the leaves that act as reactive oxygen species scavengers (Hayakawa and Agarie, 2010), the presence of betacyanins in the chlorenchyma cells of some cacti suggests that at this level they may also serve as antioxidants.

The presence of betacyanins in the cactus hypodermis suggests a screening function for these pigments allowing a reduction in photon flux, thus protecting the photosystems present in the underlying chlorenchyma, while a possible antioxidant role can be assumed for the pigments found in the chlorenchyma. Further studies in the field could elucidate if the accumulation of betacyanins in the stem is dependent only on high PAR levels or if other stresses such as drought or temperature extremes are required to promote the synthesis of these pigments, while controlled experiments could answer if betacyanins are effective screening pigments able to reduce or prevent photoinhibition. Stem reddening could be a quick visual biomarker to assess the stress level in wild populations as well as in crops and therefore may allow proper measures to be implemented to limit plant stress.

\section{Acknowledgements}

Many thanks to the 2 anonymous referees for their helpful suggestions to improve the manuscript.

\section{Literature cited}

Adams, W. W., S. D. Smith and C. B. Osmond. 1987. Photoinhibition of the CAM succulent Opuntia basilaris growing in Death Valley: evidence from $77 \mathrm{~K}$ fluorescence and quantum yield. Oecologia 71:221-228.

Anderson, E. F. 2001. The cactus family. Timber Press, Portland, Oregon. 776 p.

Cai, Y., M. Sun and H. Corke. 2003. Antioxidant activity of betalains from plants of the Amaranthaceae. Journal of Agricultural and Food Chemistry 51:2288-2294.

Clement, J. S. and T. J. Mabry. 1996. Pigment evolution in the Caryophyllales: A systematic overview. Acta Botanica 109:360-367.

Cockell, C. S., J. Berry, A. Southern, A. Herrera and C. Yackulic. 2004. Protection from UV radiation in the economic crop, Opuntia spp. Economic Botany 58:S88-S100.

Darling, M. S. 1989. Epidermis and hypodermis of the saguaro cactus (Cereus giganteus): anatomy and spectral properties. American Journal of Botany 76:1698-1706.

Fondom, N. Y., S. Castro-Nava and A. J. Huerta. 2009. Photoprotective mechanisms during leaf ontogeny: cuticular development and anthocyanin deposition in two morphs of Agave striata that differ in leaf coloration. Botany 87:11861197.

Gibson, A. C. and P. S. Nobel. 1986. The cactus primer. Harvard University Press, Cambridge, Massachusets. 286 p.

Gill, M. 1994. Pigments of fungi (macromycetes). Natural Product Reports 11:67-90.

Gould, K. S. 2004. Nature's swiss army knife: The diverse protective roles of anthocyanins in leaves. Journal of Biomedicine and Biotechnology 5:314-320.

Gould, K. S., T. C. Vogelmann, T. Han and M. J. Clearwater. 2002. Profiles of photosynthesis within red and green leaves of Quintinia serrata. Physiologia Plantarum 116:127-133.

Hatier, J. H. B. and K. S. Gould. 2009. Anthocyanin function in vegetative organs. In Anthocyanins, biosynthesis, functions, and applications, K. Gould, K. Davies and C. Winefield (eds.). Springer, New York. p. 1-19.

Hayakawa, K. and S. Agarie. 2010. Physiological roles of betacyanin in a halophyte, Suaeda japonica Makino. Plant Production Science 13:351-359.

Ibdah, M., A. Krins, H. K. Seidlitz, W. Heller, D. Strack and T. Vogt. 2002. Spectral dependence of flavonol and betacyanin accumulation in Mesembryanthemum crystallinum under enhanced ultraviolet radiation. Plant, Cell \& Environment 25:1145-1154.

Image J, U. S. National Institutes of Health, Bethesda, Maryland, USA. http://rsbweb.nih.gov/ij/; last access: 12.I.2011.

Loza-Cornejo, S. and T. Terrazas. 2003. Epidermal and hypodermal characteristics in North American Cactoideae (Cactaceae). Journal of Plant Research 116:27-35.

Mauseth, J. D. 2006. Structure-function relationships in highly modified shoots of cactaceae. Annals of Botany 98:901926.

Monje, P. V. and E. J. Baran. 2002. Characterization of calcium oxalates generated as biominerals in cacti. Journal of Plant Physiology 128:707-713.

Monje, P. V. and E. J. Baran. 2004. Complex biomineralization pattern in cactaceae. Journal of Plant Physiology 161:121123. 
Monje, P. V. and E. J. Baran. 2005. Evidence of formation of glushinskite as a biomineral in a Cactaceae species. Phytochemistry 66:611-614.

Murata, N., S. Takahashi, Y. Nishiyama and S. I. Allakhverdiev. 2007. Photoinhibition of photosystem II under environmental stress. Biochimica et Biophysica Acta (BBA) - Bioenergetics 1767:414-421.

Nakata, P. A. 2003. Advances in our understanding of calcium oxalate crystal formation and function in plants. Plant Science 164:901-909.

Neill, S. O. and K. S. Gould. 2003. Anthocyanins in leaves: light attenuators or antioxidants? Functional Plant Biology 30:865-873.

Nobel, P. S. 1988. Environmental biology of agaves and cacti. Cambridge University press, Cambridge. 270 p.

Pierce, S. 2007. The jeweled armor of Tillandsia-multifaceted or elongated trichomes provide photoprotection. Aliso 23:44-52.

Powell, A. M. and J. F. Weedin.2004. Cacti of the Trans-Pecos $\&$ adjacent areas. Texas Tech University Press, Lubbock, Texas. 509 p.

Robinson, S. A. and C. B. Osmond. 1994. Internal gradients of chlorophyll and carotenoid pigments in relation to photoprotection in thick leaves of plants with crassulacean acid metabolism. Functional Plant Biology 21:497-506.
Stafford, H. A. 1994. Anthocyanins and betalains: evolution of the mutually exclusive pathways. Plant Science 101:91-98. Steyn, W. J., S. J. E. Wand, D. M. Holcroft and G. Jacobs. 2002. Anthocyanins in vegetative tissues: a proposed unified function in photoprotection. New Phytologist 155:349-3.

Stintzing, F. C. and R. Carle. 2004. Functional properties of anthocyanins and betalains in plants, food, and in human nutrition. Trends in Food Science \& Technology 15:19-38.

Tanaka, Y., N. Sasaki and A. Ohmiya. 2008. Biosynthesis of plant pigments: anthocyanins, betalains and carotenoids. The Plant Journal 54:733-749.

Terrazas-Salgado, T. and J. D. Mauseth. 2002. Shoot anatomy and morphology. In Cacti, biology and uses, P. S. Nobel (ed.). University of California press, Berkeley, Los Angeles, London. p. 23-40.

Vidal-Zepeda, R. 2005. Las regiones climáticas de México. Instituto de Geografía-UNAM, México. 210 p.

Vogt, T., M. Ibdah, J. Schmidt, V. Wray, M. Nimtz and D. Strack. 1999. Light-induced betacyanin and flavonol accumulation in bladder cells of Mesembryanthemum crystallinum. Phytochemistry 52:583-592.

Wybraniec, S., P. Stalica, A. Spórna and Y. Mizrahi. 2010. Profiles of betacyanins in epidermal layers of grafted and light-stressed cacti studied by LC-DAD-ESI-MS/MS. Journal of Agricultural and Food Chemistry 58:5347-5354. 